\section{B A Institute of \\ YK Business Administration \\ 六下 \\ Karachi \\ Leadership and Ideas for Tomorrow}

Business Review

Volume 6 Issue 1 January-June 2011

$1-1-2011$

\title{
Global challenges for SMEs in Sri Lanka and Pakistan in comparative perspectives
}

S.W.S.B. Dasanayaka

University of Moratuwa, Sri Lanka

Follow this and additional works at: https://ir.iba.edu.pk/businessreview

Part of the Entrepreneurial and Small Business Operations Commons

(c) (i)

This work is licensed under a Creative Commons Attribution 4.0 International License.

\section{Recommended Citation}

Dasanayaka, S. (2011). Global challenges for SMEs in Sri Lanka and Pakistan in comparative perspectives. Business Review, 6(1), 61-80. Retrieved from https://doi.org/10.54784/1990-6587.1182

This article is brought to you by iRepository for open access under the Creative Commons Attribution 4.0 License and is available at https://ir.iba.edu.pk/businessreview/vol6/iss1/5. For more information, please contact irepository@iba.edu.pk. 


\title{
ARTICLE
}

\section{Global Challenges for SMEs in Sri Lanka and Pakistan in Comparative Perspectives}

\author{
S.W.S.B. Dasanayaka \\ University of Moratuwa, Sri Lanka
}

\begin{abstract}
The Small and Medium Scale Enterprises/Industries (SMEs) function as a lifeline in informal sectors of Pakistan and Sri Lanka due to their immense contribution in areas such as employment generation, exports, equitable income distribution, social stability, efficient domestic resources usage and regional development. However, a large number of SMEs in both countries are struggling to survive in today's global competitive market. Their sustainable growth is threatened by the impact and challenges of rapid globalization. Absence of any networking and cooperation among the SMEs and lack of linkages with large scale industries have aggravated these problems. In spite of the various policy reforms, establishment of SME related apex bodies, incentives and assistance offered by the national governments in both countries, SME sector has suffered in many fronts. The outcome of this paper is to identify coherent policies and strategies to develop SMEs to their full potentials both in Sri Lanka and Pakistan under this intense globalization move.
\end{abstract}

Key words: Small and Medium scale industries: SMEs, competitive dynamics, development, globalization, technology, sickness, Pakistan and Sri Lanka.

JEL Classification: L, M and $\mathrm{O}$

\section{INTRODUCTION}

The South Asian region is the cradle of small industry and the small businesses for centuries. The sub-continent especially has been the center stage of a civilization which has excelled in skills, craftsmanship and innovation. The craftsmanship passed on from one family or clan to another can be seen in metal working, precious metals and stones, jewellery, textiles, wood work, foot wear, leather work, embroidery, furniture and architecture. The craftsmanship became the focus of the early industrial development. It relied upon low mechanization but high manual workmanship and customization. With the advent of industrial revolution, mechanization in various degrees got introduced in production function. The economy of size became an important factor to the cost of the product and this became the first threat to the sector. The sector continued to thrive and grow as an important component of the economy because of its inherent strengths of high 
entrepreneurship and a strong motivation to succeed. The government subsidies, reservations, controls and regulation provided it supports. Over the years the small scale sector has taken a new shape in the form of small and medium scale enterprises, SME. The definition of the small scale has undergone a revision several times in the last few decades in both countries (Dasanayaka.S, 2009a). Globalization and liberalization inducted in late eighties/early nineties brought in new challenges. In spite of the various policy reforms, incentives and assistance offered by successive governments in India, Pakistan and Sri Lanka, SME sector has suffered the most from many handicaps and problems. The growth and expansion of SMEs are constrained by problems relating to both product and factor markets.

In this context, this paper captures the challenges and their impact as faced by SMEs in this era of globalization. The study explores as to how the small scale industry can rise to its full potential in the changed economic scenario. It examines what steps could be necessary to position the sector in its rightful place. Specifically, the paper endeavors to seek response to such questions as:

Q1: What constitutes the economic environment of globalization?

Q2: What are the new challenges faced by SMEs in this era of globalization?

Q3: How do the SMEs compare in the two countries?

Q4: How is SME getting impacted by globalization?

Q5: How should SME react and what measures should it adopt to meet the challenges?

Q6: What steps should the governments in the two countries take to promote the sector?

The first part of this paper critically assesses the main problems and constraints encountered by SMEs in the face of challenges as posed by the dynamics of globalization.

The second part of this paper highlights and compares SMEs of the two countries on common criteria. The study focuses on manufacturing business that applies high end production technologies delineated from agricultural, fishery or handicraft business and is responsible for high value addition. The third part discusses positioning of the SMEs to meet the challenges of the globalization. The paper concludes with recommendations.

Words as 'small industry', 'small sector' SME as used in this paper should be understood as synonymous terminology. 


\section{PART I}

\section{GLOBALIZATION AND SMES}

Globalization, together with liberalization of trade ushered by the new WTO regime has created a new business environment. There are new rules of business competition; customers have more choices of products and services and a paradigm shift has taken place on what counts as the success. In this section, it is first proposed to discuss what counts as globalization. Discussion on the challenges faced by an SME in the changed environment follows thereafter.

\section{GLOBALIZATION: THE ESSENCE}

Generally globalization refers to the process by which the various nations in the world are increasingly being interconnected politically and economically through international trade, financial flows and migration, etc. The focus of globalization is on easing of regulatory practices as imposed by nations on international trade covering both the imports and the exports. Globalization has brought a paradigm shift in the business environment and the rules of business. The shift is visible from policy regulation to market orientation. Globalization can be studied under two perspectives, although both of these are interrelated:

Trade liberation: The new regime ushered in by WTO regulates multilateral trade and asks the signatories to remove various restrictions on imports. Generally WTO agreements underline two important principles (WTO, 2010):

- Most favoured nation clause: It encourages non discrimination amongst member countries. It calls for restricting governments from subsidizing, dumping or enforcing discriminatory licensing policies which may hurt business within the country or outside the country. All the member nations are to bring down the tariff rates to WTO stipulated limits, without any quantitative restrictions on imports.

These provisions ask the SME's to compete with local produce from manufacturers, large and small; secondly with high quality and technologically advanced products from developed economies and thirdly to compete with low priced products with acceptable quality from developing nations.

-National treatment clause: It implies that the member countries will consider equal treatment to imported and domestic good thereby prohibiting any preferential treatment for local firms. The state shall no longer extend protections in 
the form of product reservations, licenses, restrictions on foreign companies for entry to local markets, subsidies etc.

Internationalization of production, distribution and marketing: This is the core perspective of globalization. An enterprise has access to both resources and the market beyond the national boundaries. This refers to opening of world economies unleashed: unleashing of world economies on one hand it is an opportunity to reach markets hitherto unexplored and reap the benefits, but simultaneously it also means facing the challenges of competition. The world trade has been protected through provisions of TRIPS (Trade Related Intellectual Property Rights), TRIMS (Trade Related Investment Measures) etc.

\section{CHALLENGES AND IMPACT OF GLOBALIZATION}

Globalization has brought major changes in the working of an SME. There are both direct impacts as well as indirect influences. Major areas of impact are studied under this section

\section{RISE OF MULTINATIONALS}

The intense competition has increased pressures on transnational corporations to reduce their number of suppliers with a view to bring down prices through benefits of large batch sizes. This has resulted in reduction of number of SMEs as suppliers to these organizations which constituted as the bulk of the customers.

There is a more serious larger dimension to the rise of multinationals. Bhavani (2006) argues that internationalization of production, distribution and marketing has given rise to global commodity chains that are the network of business units of different sizes involved in various stages of a product beginning from the supply of raw materials and components to production, marketing and retailing spread across the countries. Apparently organizations of these operations are massive in scale and investments. Small retailers, brand merchandizes and small plants cannot control these chains. As globalization expands, the chains will take over business controls of small plants. And dictate rules of operations.

\section{CHANGES IN SOURCING BASE}

Bhavani.A (2006) says that the international chains can be producer driven or buyer driven. Producer driven chains exist for capital and technology- intensive products where the manufacturer of the final product is the key economic agent. As an SME unit is on weak grounds in technology it has only a limited role in producer-driven chains. In contrast buyer-driven chains exist for market-intensive products that are also labor-intensive. International chains will look for sources of such products or 
services which match buyer's expectations in terms of price, quality and delivery. Low prices are generally associated with economies of scale, automation and specialist technologies of mass production areas. Globalization has reduced the range of products in the domain of SMEs as the small scale sector just cannot match the costs of production in a large set up based on mass production.

\section{CHANGE IN CONSUMER PROFILE}

The impact of globalization on customer taste and preferences is reflected in several dimensions. Globalization has brought a paradigm shift in expectations, aspirations and the social habits of consumers. Attachment to the domestic produce as a component of nationalistic fervor is getting diluted day by day.

\section{CHANGE IN CUSTOMER PREFERENCES}

A common code of culture encompassing dress, fast food, use of leisure, entertainment, travel habits, life style is fast developing across countries at the expense of local tastes, ethnic preferences and national habits. Revolution in information technology, the spread of the internet, the electronic media and easy expanding tourism traffic has made the customer well informed and knowledgeable about the availability of the products/services and their specifications across the national frontiers.

\section{EASY PROCUREMENT}

Fashion or innovation introduced in France or Germany travels fast and reaches consumers in no time. There is an immediate demand and an aspiration to be in the front line with other consumers. The global courier services, expanding airways network, simplified import procedures, removal of restrictive trade practices, EProcurement and online orders have brought the product/services within the ambit of instant purchase by a customer.

\section{GROWING PURCHASING POWER}

There is a perceptible change in the purchasing power. Millions of high purchasing customers are being added every year in the developing economies. Pakistan and Sri Lanka along with other developing economies are the new centers of consumption. With increase in purchasing power, consumer goods, health care, education, travel, leisure vocations will be more in demand. 


\section{CUSTOMER IS THE KING}

It is for the first time that a customer is coming to be considered as a king in the emerging economies because he and Gives money to you. He has a choice. He can compare the prices, quality, delivery, flexibility and service as offered by various manufacturers. He asks for product differentiation, customized designs and innovative features.

\section{LOCATION OF MANUFACTURING FACILITIES}

Economists recognize that different countries have different comparative strengths and weakness and the strengths form the backbone of industry. Pakistan and Sri Lanka have been known to possess advantages of low cost of labour. Besides this, economies have the advantages of availability of raw materials: steel, aluminum, cotton, leather, high quality fruits in Pakistan; gems and tea in Sri Lanka.

The two countries are also blessed with moderate climate, saving huge expenses to provide heating as is the practice in the advanced economies of the west. These comparative strengths have added to the survival and growth of the small industry. However, globalization has encouraged more and more firms to shift their manufacturing capacity from advanced industrialized countries to developing economies. These are often at the cost of the local small industry.

\section{CHALLENGES OF TECHNOLOGY}

Technological change has emerged as the foremost component for competitive advantage. A firm possessing the latest technology and a capacity to bring about faster change in the application has competitive advantage. There are other developments in technological environment created by globalization for example product life cycles have been shortened. There is now less time between the introductions of the product to the stage of maturity. The development time, that is, the time taken to develop a technology to a marketable product, is reduced. Today there is a trend of decreasing payback period, that is a pressure to yield reasonably quick return on investments. These facts are recognized by the large sector which has increased its spending on R\&D in recent years. Small industry, already handicapped, has no resources to compete on the research forum.

\section{PARADIGM SHIFT IN NATIONAL PRIORITIES}

There is a virtual race in both countries to attract foreign investments, opening of the domestic markets to foreign produce and permitting entry of multinationals in areas such as retail trade, processed food which have been the traditional strongholds of small scale sector since centuries. On the other hand, no concrete steps are visible to 
promoting the SMEs and their produce. The initiatives have resulted in high growth rate and rising GDP, but simultaneously the decline of SMEs have brought losses in employment, ever increasing disparities of income and regional imbalances. The unrest in specific geographical regions of the two countries can be traced to non existence of opportunities for jobs and development.

\section{PART II}

This section makes a comparison of the state of affairs of SMEs in two countries. To make a fair evaluation it is necessary to choose the same categories and criteria. This task is further complicated in three ways. There is no common definition of an SME in the region. The situation is worse in Pakistan and Sri Lanka where several definitions are in vogue as followed by several institutions. Secondly, the definitions are based either on investments made in the fixed capital, turn over, or the number of persons employed. But these parameters are not justified. Lastly, the definitions have undergone frequent changes. As a result, the data available is fragile and not sufficient justified for analysis for a present day business environment. The author has chosen three categories for the comparison:

Profile: This lists the basics, including the numbers, growth and the contribution to the domestic economy.

Business Development Support: Govt. as well as non- government important agencies active in the promotion of SMEs are mentioned.

Constraints: Only such constraints which are largely specific to the country are discussed. Constraints common to two countries are discussed in a separate section.

\section{THE STATUS: SMES IN PAKISTAN}

\section{PROFILE}

Researchers such as Dasanayaka.S and Sardana.G (2008b, 2009b); Sardana.G and Dasanayaka.S (2007), and Dasanayaka.S (2008b) point out that Pakistan is a cradle of SMEs as more than $90 \%$ of industrial and business enterprises fall in this sector. It employs $80 \%$ of the non-agricultural labor force and contributes nearly $40 \%$ to the national GDP. The Small and Medium Enterprises Development Authority (SMEDA) of Pakistan pointed out 3.2 million business establishments exist in Pakistan and out of that $99 \%$ are SMEs which employ less than 99 persons. These establishments have employed more than $78 \%$ country's non-agricultural labour force. They contribute over $30 \%$ to GDP and account for $25 \%$ of manufacturing exports besides sharing $35 \%$ of value added manufacturing (SMEDA, 2007). The sports goods, leather work, carpet weaving, crafted wood work known for their 
workmanship, creativity, innovations and attractive appearance have created a name all over the world. Pakistani economy has a high potential for growth with promotion and development of SMEs. However, in practice most of the government- led institutions established since early years of political independence to facilitate business promotion have been concentrating their efforts on large scale industry. SMEs in Pakistan are hindered by economic slumps, tax policies, law and order problems, general risk aversion of banks, institutional malpractices, political instability, unskilled labour, insufficient and low quality production, obsolete technology and lack of overall policy directions. Absence of a single SME definition makes it difficult to collect data and monitor the progress of SMEs over time.

Federal Bureau of Statistics $(2000,2003,2004)$ shows that geographically 65 percent enterprises are located in Punjab, 18 percent in Sindh, 14 percent in NWFP and other 3 percent in Balochistan and Islamabad. In categories, 53 percent of enterprises are wholesale, retail, restaurants and hotels, 22 percent are community, social and personal services and 20 percent are in manufacturing. More than 96 percent of these establishments employ less than 5- employees. This holds good for region-wise distribution as well. Ownership-wise more than 96 percent enterprises belong to individuals and this picture holds good for regions as well. Age wise, more than 90 percent of SMEs are less than 20 years old and this picture is true for both rural and urban areas.

A large proportion of industries concentrate on a few categories: 43 percent industrial establishment are in textile, apparel and leather, 20 percent in food, beverage and tobacco, 10 percent in wood and wood products, 10 percent in metal and fabricated metal sector and 8 percent in handicrafts and related other activities. This shows Pakistan's heavy concentration in the textile, apparel and leather sector. Overall female labour participation is very low, at about 7 percent and of the same 3 percent is unpaid, as these are they are part of partnerships or/and self-employed family workshops. Fifty percent of total SMEs activity is concentrated in five subsectors; grain milling, cotton weaving, wood and furniture, metal products and art silk. Micro, Small and Medium Enterprises (MSMEs) contribute around 7 percent to the GDP, and 9 percent to agricultural GDP.

The high value adding engineering goods manufacturing in the SME sector constitutes a poor presence. The reasons lies in the absence of large manufacturing activity which could provide horizontal and vertical linkages which is why neither the SMEs have been successful in establishing any major exports. Pakistani SME, have largely confined to cottage and the micro industry where the manual traditional skills dominate (Dasanayaka.S and Sardana.G, 2009a). 


\section{BUSINESS DEVELOPMENT SUPPORT}

There are a large number of both government and non-government bodies active to support business development. SMEDA is the government apex body for development and promotion of SME sector in Pakistan. Apart from policy formulation and sector development strategies it aims at facilitation of business development for the SMEs. Resource Monitoring and Development Group (RMDG) and its partners are engaged in helping the Government of Pakistan to develop a more competitive and sustainable agri-business sub sector. The Mennonite Economic Development Agency (MEDA) and the Entrepreneurship Career Development Institute (ECDI) assist to develop local garment markets and distribution systems to reach rural, home-bound women. MEDA and ECDI are also participants in the United States Agency for International Development-funded (USAID) Small Enterprise Education and Promotion (SEEP) Practitioner Learning Program (PLP). These bodies focus on three promising sectors: garments, handicrafts, and ICT. Many of the rural, home-bound women, who produce the clothing, sell primarily at the low value, traditional, rural markets through intermediaries. Aga Khan Rural Support Program (AKRSP) encourages the development of markets in remote areas of northern Pakistan. AKRSP is a private, non-profit company, established in 1982 by the Aga Khan Foundation to help improve the quality of life for the villagers of the Northern Areas and Chitral in Pakistan.

It acts as a catalyst for rural development, organizing local human and financial resources in order to enable the communities to bring about their own development in an equitable and sustainable manner. AKRSP started the "Shubinak" project in the Chitral district, one of the poorest rural areas of Pakistan, to improve the economic base and livelihoods of the rural population - particularly women - by reviving the "shu" industry. Shu is an indigenous, handmade wool fabric, which women in Chitral have been making for centuries. Taraqee Foundation is a NonProfit Government Organization (NGO) established in 1996 to alleviate poverty in Balochistan through gender sensitive, people centered approaches by providing a set of social and economic services. It has been active to support people in developing entrepreneurship. Kashf Foundation, Lachi Poverty Reduction Project, Akhuwat and many more similar NGOs promote sustainable rural livelihoods through the promotion of village based self help groups, which provide income generation activities through physical infrastructure projects, savings and credit programs and enterprise development. National Rural Support Program (NRSP) is a NGO working with the government in NWFP on community development, Community contribution and cost recovery. While Sarhad Rural Development corporation, a NGO is working with provincial government on training, saving and credit programs, Balochistan Rural Support Program, another NGO is working on training and credit programs. 


\section{CONSTRAINTS TO GROWTH OF PAKISTAN SMES}

There are very many binding constraints in Pakistan which limit the growth of SMEs. Some of the important constraints specific to Pakistan are discussed as under.

(a) Absence of sizeable large scale sector

Pakistan lacks the existence of a large scale manufacturing sector. Current manufacturing model, as advanced by Toyota Manufacturing System and accepted all over the world calls for assembly lines to be supported by efficient supply chains and JIT systems in supply of parts sourced from SMEs. Automobiles, white goods, domestic consumables, fans, bicycles, project engineering are some products which come in this category. Pakistan lacks in this sector. Apparently, there is hardly an opportunity for SMEs to venture in engineering goods.

(b) Infrastructure Constraints

Poor infrastructure, low quality of service, non-reliability, corruption in obtaining supplies, and politically influenced tariffs are the main anchors of the power constraint. Evidence depicts that Pakistan's state controlled and concentrated infrastructure is highly inefficient. The power transmission and distribution losses including power theft

are reported to be the highest in Pakistan compared to other South Asian countries (World Bank, 2005). Similar inefficiencies are also characterized in Pakistan's road, sea, airports, railways system and the customs.

\section{(c). Human Resource and Entrepreneurial Skill Constraints}

The overall quality of education and training offered in Pakistan is poor even in South Asian standards. Pakistan's literacy rate is low and to be specific, it is around $61.7 \%$ and $35.2 \%$ among the male and female respectively (www.cia.gov). Low educated and skilled workforce pose problems when it comes to transfer of product or process technology, a major requirement for the growth of the sector. SMEs inability to appropriate the returns on investment and enforce contracts deters investing in managerial and worker training. There is a significant mismatch in the skills required by employees and the training offered by institutions. Especially in Pakistan entrepreneurship culture does not exist and most of the educated youths are mainly job seekers rather than job creators. Therefore many initiatives have to be taken to create a true entrepreneurial culture in this country. Some of these initiatives can be promotion of entrepreneurship education at school and University level, training people to take risks for better gains, national and regional level business plan competitions, linking universities and industry, identifying and developing country's best brains as entrepreneurs, setting up of business and technology incubators, 
welcoming foreign entrepreneur talents and expatriates under new immigration policy and incentive schemes, less regulated and more flexible labour market, promotion of venture capitalist and angel financing industry, etc.

\section{THE STATUS: SMES IN SRI LANKA}

\section{PROFILE}

Sri Lankan SMEs are engaged in a wide range of business activities in agriculture, mining, fisheries, industry/manufacturing, construction, tourism and services in rural, urban and estate settings by servicing local and international markets (Department of Census \& Statistics 2006). Most Sri Lankan SMEs are one-person activity or are run by family individuals, usually relatives, friends or business partners. Most Sri Lankan SMEs in informal sector report very low productivity and income; therefore owners and workers are 'working poors' but SMEs in formal sector report very high productivity and efficiency and generate high income (Dasanayaka.S, 2007a, 2008a). In recent times, there is a growing emphasis on Micro, Cottage and Small Scale Enterprises as instruments to promote employment. Policy makers have stressed that micro, cottage and small enterprises instead of medium scale enterprises, should receive more government care and attention (Dasanayaka.S, 2007b).

Galagoda.S (2008) quotes World Bank that SMEs make up more than 80 percent of all businesses, account for about 35 per cent of employment and about 20 percent of total industrial value addition. Altogether 96 percent of industrial establishments are in SMEs but their contribution to value addition is not as high as compared to large scale enterprises and more importantly the contribution is decreasing over the years (Department of Census \& Statistics 1984, 1997). Large scale establishments account for less than 4 percent of total establishments but their contribution to value addition is around 80 percent. Gamage.A (2009) refers that there are only 2 percent of large establishments in the category of manufacturing, but the same account for more than 50 percent of output. Dasanayaka.S (2007a) reports that geographically, small industries are concentrated in western districts of Colombo (10 percent) and Gampaha (13 percent) and North-Western district of Kurunagala (14 percent). While SMEs are not developed at all in Northern province of Jaffna, Mannar, Vavunia, Mulativu and Kilinochchi.

A large proportion of industries ( 80 percent) are concentrated in four groups of industries and these account for 80 percent of employment generation. These industry categories are: i) Food, beverage and tobacco products. ii) Textile, apparel and leather products. iii) Non-metallic mineral products iv) Mining. A general lack of dynamism and a stagnant nature in the form of non- diversification of SMEs has come to pervade over the years. 
Dasanayaka.S (2009b) refers that Most of the SMEs have not succeeded to gain the advantages of economies of scale because business units operate in isolation with the inadequate total assets and management skills. Similarly, the study reports that SMEs have poor horizontal business linkages.

\section{BUSINESS DEVELOPMENT SUPPORT}

Gamage.S (2003) and Dasanayaka.S (2009b, 2008b) traces the history of SME developments in Sri Lanka. It is only after 1977, that there has been an encouragement provided to the sector. Effective institutional support is mostly organized on product lines. Sri Lankan tea is recognized as the top quality tea at global level. This has been possible because of sincere dedicated efforts of a number of institutions. These include Tea Research Institute (TRI), Tea Small Holdings Development Authority, the National Institute of Plantation Management (NIPM), and Tea Planters Association. TRI helps the plantations in providing technological know-how to increase the yield and improve the quality. TRI also publishes Tea Bulletins and Information Memorandums on a regular basis to enlighten the industry on latest developments, pest and weed management guidance and new technological advances such as the field practices, clones etc. Formal training programs are conducted by NIPM adding to the accumulated knowledge available through work experiences. The NIPM offers a range of training courses available to all levels of staff of an estate, from the field workers to the estate managers.

Similarly, Sri Lankan gift and decorative were SME industry employs over 200,000 persons, is well organized and basis its success on innovative technology (Dasanayaka.S and Sardana.G, 2008). Some of the other prominent institutional support to the sector include:

Ceylon Institute of Scientific and Industrial Research contributes to the development and dissemination of appropriate technology. The Department of Rural Development and Cottage Industries is the main institution responsible for the cottage sector. Laksala has objectives to solve marketing problems of handicraft manufacturers. Industrial Development Board is the apex body established in 1956 with main objectives of promoting and developing SMEs in the industrial sector. Small Enterprise Development Division has primary objectives of encouraging selfemployment, and Department of Textiles assists the cottage sector in development of new designs and better utilization of raw materials. The Peoples Bank, The Bank of Ceylon, Regional Rural Development Bank are established to provide credits and loans to the sector. Sri Lanka Business Development Centre and Sarvodaya Management Training Institute are important NGOs to provide facilities for training. 


\section{CONSTRAINTS TO GROWTH OF SRI LANKAN SMES}

(a) Lack of organized large sector:

The situation is worse as contrasted to Pakistan. Large manufacturing corporations are just not there except garments. As a result there are no linkage opportunities available for the small sector. In garment sector forward and backward linkages are not in the country. Generally good linkages bring additional advantages of diffusion of industrial skills which encourage entrepreneurship. In case of Sri Lanka, this constraint is also responsible for lack of trained and skilled manpower for the manufacturing sector (Dasanayaka.S, 2007b).

(b) Lack of Infrastructure and raw-materials:

In addition to serious bottle necks in infrastructure, Sri Lanka is deprived of oil and coal, the all important resources of power needed for industry. It has to depend entirely on imports thus pushing the cost of generation of power to one of the highest in the region. In similar context, the country has also no known deposits of minerals except few potassium deposits.

(c) Civil strife and Governance related problems:

The nation has been in the midst of unfortunate civil strife for the last three decades. All the resources have been diverted to control the strife. This has resulted in virtual zero industrial development in a large area of the country. Even though this North and East problem is over many civil unrests and various types of governance related problems have emerged in Southern Sri Lanka.

\section{CONSTRAINTS COMMON TO BOTH COUNTRIES}

\section{( a) FINANCE RELATED CONSTRAINTS}

Dasanayaka.S $(2007 a, b)$ refers that major sicknesses of a small industry arise from inadequacy of working capital, delays in sanction and disbursal of working capital, gaps between sanction of term loan and working capital, and poor credit management. High interest rates and collaterals are the most cited issues. Most SMEs feel that they have discriminative treatments by the banking sector compared to services offered to large scale enterprises. There is a general indifference and lack of trust which the banks and the financial institutions carry in sanction of loans. SMEs often complain that large scale enterprises can easily access other credit instruments in capital market which SMEs are not allowed. Obtaining loans from traditional financial market is very difficult due to excessive paper work, and high collaterals due to high risk involved in SME finance. SMEs own characteristics such 
as problems of proprietorship, poor resource base, non-existence of economies of scale and scope, etc. iggravate this situation. SMEs get their finance from very costly informal market and finally they get in to debt trap. The Small or micro enterprises (SE), in particular, including smallholders suffer from lack of collateral securities. Most banks prefer land as collateral but in most cases more than $80 \%$ land belongs to the government and the land owned by SMEs does not have clear deeds to bank them as collateral (Dasanayaka.S, 2008b). In addition, banks always insist on well prepared business plans and feasibility reports, where SMEs are handicapped. Most banks prefer to provide finances to urban based SMEs rather than rural based. Third finance related problem is the cost of finance. Lack of financial management experience and financial discipline, over ambitious business acceleration, lack of professionalism in business, non-separation of personal and enterprise expenditure, demonstration effects and unnecessary expenditure such as expensive imitative life style are some other reasons.

\section{(b) MARKETING RELATED CONSTRAINTS}

The small sector products are simply priced out by products from large manufacturers which are less costly as the result of economies of scales and scopes. A large undertaking has additional advantage of a brand, large budget for promotion and publicity, product positioning and geographical reach. Information on local preferences helps larger units to customize products to local tastes. Benefits of globalization have not reached the SMEs as the sector is just not aware of the demand, local preferences, sources of supply of raw materials, information on costs, market prices, and supply chains. In spite of large network of institutions created to promote the SMEs in all the three countries, there is hardly any worthwhile contribution reported in this direction. In most cases, export houses, large retail houses become the customers and exploit these SMEs. Workers and SMEs owners stay forever as working poor, making the export houses and the super malls/retail malls richer.

\section{(c) TECHNOLOGY RELATED CONSTRAINTS}

Technology refers to all aspects of product design, innovation, product development, processing technology, and engineering applications in storage, preservation, transportation and distribution. SMEs lack the resources to go for basic research or radical innovation. Besides there are problems even to source technology. Foremost problem lies in ignorance in identification of suitable technology, the importance of technology in product quality and productivity improvement, access to technology and sources of its availability. SMEs cannot opt technology, suitable for automation, or mass production. Therefore, the industry depends on technology resource from research establishments. None of the three countries can boast of real contribution in path breaking research, or development of new products. The universities, institutes 
of higher learning, the management schools, universities and research laboratories have only an insufficient and limited interface with SMEs to render any assistance in these dimensions (Dasanayaka.S, 2007b). Pakistan and Sri Lanka ,both lack the infrastructure of scientific personnel and the research labs. It is a case of potential wasted India, produces globally the largest number of engineering graduates, management post- graduates and IT personnel every year. For more detailed studies on selected SMEs technology related problems in both countries see Dasanayaka.S and Sardana.G (2008b, 2009b).

\section{(d) MISPLACED NATIONAL PRIORITIES}

The politico-economic leadership in all the two countries recognizes the contribution of the small sector to the national objectives of generation of employment, reducing disparities of income and regional development. However, in practice all the national economic policies are skewed in favour of the transnational corporations and the large sector. This is reflected in the fiscal policies, the bank interest rates, advancement of loans, sanction of large projects, setting up of economic zones and concessions to attract foreign direct investments through major tax benefits as attractions. Assistance needed by the small scale is recognized in the form of easy and low interest credit, technology up-gradation, promotion of exports, easy rules on regulation, time bound sanctions. The policies formulated and the implementation lack in all these dimensions. The impact is evidenced in rising unemployment, increasing disparities in income and poor social development and civil unrest in both countries.

\section{PART III}

\section{POSITIONING FOR THE CHALLENGES}

SME has its own limitations and inadequacies such as the smallness of size operations, structure and decision making, dependency on owner, inadequate management controls, unfavorable power balance, lack of product brand and shortage of funds. The inadequacies are now accentuated under new paradigm of competitiveness emerged under globalization.

\section{(a) HORIZONTAL AND VERTICAL ALLIANCES}

This type of cooperation can take various forms. SMEs join hands, become a member of network of firms and make a common offer to large customers as super malls/retail houses or for exports. In a vertical alliance the units gain through incorporation in global value chains. Large organizations and multinational corporations take necessary steps in such linkages to improve capabilities and technological know-how of their suppliers. Units situated in a cluster are another 
type of an informal alliance where the units get access to skills and experiences. The cluster units support each other, improving productivity, quality and core competency. Over a span of time these units establish their own name, brand and customer acceptance. The clusters become a common address to large customers. The success story of Pakistan SME to a large extent is the success of such linkages with large organizations especially in the automobile, tractors, machine tools, project engineering and heavy electrical sectors.

\section{(b) ENHANCEMENT OF CHANGE CAPABILITIES: INNOVATION}

The rising income and the addition of new customers have opened up new vistas for the SME's. The increase in purchasing power has whetted the desire of consumers to ask for differentiated, unique, and customized products/services as against standardized products from large producers. These are the areas where SMEs, because of its competencies to deal with small batches, short production cycles, creativity, and ability to innovate at short intervals, excel and operate more efficiently. This is also the area where a customer is willing to pay more. The fashion products, apparel, foot wear, jewellery, cosmetics, decorative house fittings, furnishings, furniture, crockery, crafted products, table ware, gift items and more fall in this category. There is an enormous increase in demand of services. Generally SMEs have remarkable strengths in relationship management to provide products and services. SME is characterized by flexibility of operations, short cycles of production, low overheads, fast delivery and high responsiveness. These find immense need in operational environment of changed customer profile in areas of customized products and services. A SME needs to enhance its change capabilities and carry out frequent innovations in its product portfolio (Dasanayaka.S and Sardana.G, 2008a).

\section{(c) CREATION OF NICHE MARKETS}

A SME is not equipped for large scale production as well as distribution. It has an alternative of introducing even a standard product and compete with a large scale manufacturer on quality and service. The operation of marketing should get limited to nearby market thereby avoiding the costs of distribution.

\section{(d) GOVERNMENT AS A FACILITATOR}

No where in the world where SMEs have done well it has been possible to improve business support without institutional support. Sustainable SME development requires concerted efforts among all the concerned parties including financial institutions, consulting and training firms as well as local business associations. The role of the government in the process is vital but is limited to providing the enabling environment correcting potential market failures and creating a level playing field 
that will allow SMEs to compete in free market. At the same time, business development services are needed to improve the internal capability of SMEs. Government efforts under this approach are directed towards; creating conducive business environment, facilitating SMEs access to markets, enhancing information flow, promoting entrepreneurial culture, facilitating development of services for new enterprise creation, education, and technology development (Dasanayaka.S, 2007b). To be specific, government has to be genuine to promote SMEs and needs to usher in policy reforms in providing updates on national and international markets, access to finance on rates lower than applicable to large firms, technological consultancy on product research and product development, training of manpower and performance orientation in transactions and specially finding overseas market through their diplomatic missions.

\section{CONCLUSIONS}

The economic policy makers in both countries accept that the paramount importance of SMEs contribution for economic growth and development. Especially the only route to solve the burning problems of unemployment, poverty and regional disparity lies in the hands of SMEs. The leadership is indeed quite vocal when it comes to expressing its support to the promotion of the sector. There are compelling reasons for the leadership to promote this sector. The economic rationale for assisting SMEs lies in facts that these units often use domestic resources more efficiently than larger enterprises when market imperfections prevent them from maximizing the benefits of their efficiency advantages. SMEs are important contributors to pro-poor growth that the large scale enterprises cannot match. Furthermore, most SMEs are managed by their owners and therefore have a greater incentive to manage everything efficiently with more flexibility. An increase in the number of competitive SMEs should contribute to poverty alleviation. As the SME-sectors grow, competition for labour (especially skilled labour) can be expected to push up wage levels. Sometimes this may be start of losing comparative advantage of labour in one hand and other is wage level will increase to modern formal sector wage level on the other (Dasanayaka.S, 2009b). Ultimately the poor will benefit from improved availability of goods and services and access to markets. In terms of employment creation, medium sized firms will be in the best position to expand if business development services and credit can be made easier available. State initiatives in promoting the SMEs are therefore justified. There is an absence of a clear policy to promote the same. However, globalization has brought a paradigm change in the rules of competition. SMEs are now exposed to challenges from both the domestic and the imports. The units lack in knowledge of the markets, consumer preferences, technology developments. Formulation of national policies may be desirable for each sub sector of the SMEs. Organizing public hearing meetings with SMEs are necessary to understand SMEs needs and problems over the time. But in overall, two 
countries should first understand the SME concept at ground level and their specific features before implementing policy initiatives for global challenges $\frac{\text { 戬 }}{\text { 数 }}$

\section{REFERENCES}

Bhavani. A (2006), Globalization \& Indian Small Scale Industries, Ane Books India, New Delhi.

CIA (2010), www.cio.org, accessed on 12/02/2010.

Department of Census \& Statistics (2006), Census of Industries - 2003/04, Ministry of Industries and Production, Govt. of Sri Lanka, Colombo.

Department of Census \& Statistics (1984), Census of Industries - 1983/84, Ministry of Industries and Production, Govt. of Sri Lanka, Colombo.

Department of Census \& Statistics (1997), Census of Industries - 1995/96, Ministry of Industries and Production, Govt of Sri Lanka, Colombo.

Dasanayaka.S (2007a), A brief note on Sri Lankan SMEs, in Paradigm Research Journal, Vol.X (1), page 69-76, Jan- June, ISSN No: 0971 - 8907.

Dasanayaka.S (2007b) "Business Incubators in Sri Lanka", in Cases in Business Management, Page 385 - 405, ed. By Sahay, Stough.R and Saradana..D, Allied Publishers Pvt Ltd in India, ISBN No: 81-8424-262-0.

Dasanayaka.S (2008a) "Small and Medium Enterprises in the Pacific Rim - The Case of Sri Lanka in Small and Medium Enterprises in the Pacific Rim ed by Nelson Oly Ndubisi, page 277-312, ARAH Publishers in Malaysia, ISBN 13: 978-983-3718$37-5$.

Dasanayaka. S (2008b), SMEs in globalised world: A brief note on basic profiles of Pakistan's SMEs and possible research directions, Business Review, Vol.3 (1), page 69-78, Jan-June, ISSN 1990-6587.

Dasanayaka. S (2009a), The Development of Informal Sector Small and Medium Scale Enterprises through Formation of Cluster and Networking. A Case Study based on Sri Lanka and Pakistan, Business Review, Vol.2 (2), page 102 - 122, July- Dec, ISSN 1990-6587.

Dasanayaka.S (2009b) Small and Medium Scale Enterprises, Development and Practice in Sri Lanka, TKP Publishers, ISBN No: 978-955-51487-1-9. 
Dasanayaka. S and Sardana.G (2008a), Impact of organizational culture on innovativeness of export-oriented firms - A case study of gift and decorative-ware industry in Sri Lanka, Euro Asia Journal of Management, Dec 2008 Vol. 18 No.2 pp. 103-122. ISSN No. 0872-8496.

Dasanayaka.S Sardana.G (2008b), Business facilitation through Technology Incubators in India, Pakistan and Sri Lanka: A Comparative Perspective, Market Forces, Vol.4 (2) pp 18-29. ISSN No. 1816-8434.

Dasanayaka.S and Sardana.G (2009a) SMEs in the informal sector in Pakistan and Sri Lanka, with a research agenda, Euro Asia Journal of Management, Vol. 19 (2), (Accepted, final proof completed and the process of publication).

Dasanayaka. S and Sardana.G (2009b), Technology Issues in Pakistan's Small and Medium Scale Industries in Globalize Era, The Case of Leather Industry, in Market Force, Vol.4 (4), Page 167-79, ISSN No. 1816-8434.

Federal Bureau of Statistics (2003), Census of Manufacturing Industries 2000-2001, Federal Bureau of Statistics, Pakistan.

Federal Bureau of Statistics (2000), Economic Census (2000), Govt. of Pakistan, Islamabad, Pakistan.

Federal Bureau of Statistics (2003), Census of Manufacturing Industries (20002001), Govt. of Pakistan, Islamabad, Pakistan.

Federal Bureau of Statistics (2004), Economic Survey (2003-04), Govt. of Pakistan, Islamabad, Pakistan.

Galagoda. S (2008), SMEs play critical role in a country's economy-WB Country Director' accessed www. Sunday observer.lk/2008/02/03.

Gamage. A (2003); 'Small and Medium Enterprise Development in Sri Lanka:A Review' accessed wwwbiz.meijo-u.ac.jp/SEBM/ronso/no3_4/aruna.pdf, accessed on 23/01/2010.

Sardana. G, and Dasanayaka. S (2007), SMEs: A Comparative Analysis of India, Pakistan and Sri Lanka, Productivity, Vol. 48, No 3. , pp 235-249. Oct-Dec. 2007.

SMEDA (2007). SME Led Economic Growth Creating Jobs and Reducing Poverty, Ministry of Industries, Production and special initiatives, Islamabad, available at http://www.smeda.org.pk. 
World Bank (2005) Economic Assessment Report on Pakistan, Islamabad.

WTO (2010), Understanding WTO, www.wto.org, accessed on 25/02/2010.

Knowledge workers will not be the majority in the knowledge society. But in many countries, if not most developed countries, they will be the largest single group in the population and the workforce. And even if outnumbered by other groups, knowledge workers will be the group that gives the emerging knowledge society its character, its leadership, its social profile. They may not be the ruling class of knowledge society, but they already are its leading class. And in their characteristic, their social position, their values, and their expectations, they differ fundamentally from any group in history that has ever occupied the leading, let alone the dominant, position.

Peter F. Drucker, Managing in a Time of Great Change,

page 203. 